\title{
Identifikasi Kemampuan Bakteri dari Rizosfer Kakao dalam Menghambat Phytophthora palmivora Secara In Vitro
}

\section{Identification of the Bacterial Ability of Rizosfer Cocoa in Inhibiting Phytophthora palmivora in In Vitro}

\author{
Ita Zahara ${ }^{1}$, Ainun Marliah ${ }^{1}$, Syamsuddin $^{1 *}$ \\ ${ }^{1}$ Program Studi Agroteknologi, Fakultas Pertanian, Universitas Syiah Kuala
}

\begin{abstract}
Abstrak. Phytophthora palmivora merupakan penyakit yang menyebabkan kerugian besar. Pengendalian terbaik yang harus diupayakan saat ini yaitu menggunakan pengendalian hayati dengan mengisolasi bakteri di daerah rizosfer tanaman kakao. Tujuan dari penelitian ini untuk mendapatkan isolat rizobakteri yang mampu berperan sebagai kadidat agen biokontrol. Penelitian dilaksanakaan di Laboratorium Ilmu dan Teknologi Benih Jurusan Agroteknologi, Fakultas Pertanian, Universitas Syiah Kuala, Darussalam Banda Aceh dari bulan Maret sampai Juni 2018. Rancangan Acak Lengkap (RAL) non Faktorial adalah rancangan yang digunakan dalam penelitian ini dengan parameter pengamatan yang diamati adalah persentase pengahambatan pertumbuhan koloni patogen dan laju pengahambatan pertumbuhan koloni patogen. Daya hambat isolat bakteri yang diperoleh dari rizosfer kakao terbaik ditemukan pada isolat TRIM8/9 dengan persentase $76,67 \%$ dan laju hambat 3,16 mm/hari.
\end{abstract}

Kata kunci : Isolat Bakteri, P. palmivora, kakao, pengendalian hayati

\begin{abstract}
Phytophthora palmivora is a disease that causes large losses. The best control that must be sought now is to use biological control by isolating rhizobacteria in the rhizosphere of the cocoa plant. The purpose of this study was to obtain bacterial isolates who were able to act as candidates for biocontrol agents. The research was conducted at the Seed Science and Technology Laboratory of the Department of Agrotechnology, Faculty of Agriculture, Syiah Kuala University, Darussalam, Banda Aceh from March to June 2018. Non Factorial Randomized Complete Design (CRD) was the design used in this study with observed observation variables as percentage inhibition of growth of pathogenic colonies and the rate of inhibition of growth of pathogenic colonies. The inhibition of bacterial isolates obtained from the best cocoa rhizosphere was found in TRIM8/9 isolates with a percentage of $76.67 \%$ and inhibition rate of $3.16 \mathrm{~mm} /$ day.
\end{abstract}

Keywords: Bacteria Isolates, P. palmivora, cocoa, biological control

\section{PENDAHULUAN}

Tanaman Kakao (Theobroma cacao L.) merupakan komoditi tanaman perkebunan yang memiliki peranan sangat penting dalam perekonomian negara yaitu sebagai sumber penghasilan, khususnya penyedia lapangan kerja, dan sumber devisa negara (Sunanto, 1992). Pada tahun 2015 Indonesia memiliki luas areal perkebunan kakao sekitar 1.709.284 ha dengan jumlah produksi mencapai 593.331 ton, pada tahun 2016 luas areal mencapai 1.701.351 ha dengan jumlah produksi mencapai 656.817 ton, sedangkan pada tahun 2017 luas areal mengalami penurunan yaitu 1.691 .334 ha dengan produksinya mencapai 688.345 ton (Direktorat Jenderal Perkebunan, 2016). Indonesia merupakan produsen kakao ketiga setelah pantai Gading dan Ghana, walaupn demkian kakao yang dibudidayakan oleh petani di Indonesia masih menghadapi permasalahan produktivitas dan mutu produk yang seharusnya dapat menyeimbangi posisi Pantai Gading dan Ghana. 
Aceh merupakan salah satu penghasil kakao terbaik di Indonesia. Luas perkebunan kakao di Aceh mencapai 98.233 ha dengan produksi 32.403 ton, dan produktivitas kakao di Aceh mencapai $585 \mathrm{~kg} \mathrm{ha}^{-1}$ (Statistik Perkebunan Indonesia, 2017). Hampir seluruh kabupaten di Aceh terdapat perkebunan kakao, baik itu perkebunan pemerintah, swasta maupun rakyat.

Saat ini petani masih menghadapi hambatan dalam budidaya kakao yaitu adanya organisme pengganggu tanaman (OPT) dan penyakit yang menyebabkan rendahnya produktivitas kakao di Indonesia. Penyakit yang sangat sering menyerang tanaman kakao dengan penyebarannya yang luas dan paling sering menyerang tanaman kakao dari genus Phytophthora yang menyebabkan buah menjadi busuk (pod rot) (Darmono et al., 2016). Busuk buah kakao memnyebabkan kehilangan hasil mencapai kehilangan 90\% terutama pada musim hujan dan kemarau (Rosmana et al., 2010).

Beberapa spesies Phytophthora yang menyebabkan penyakit pada kakao yaitu Phytophthora palmivora, Phytophthora citrophthora, Phytophthora megakarya, Phytophthora capsici, Phytophthora katsurae, Phytophthora megasperma, Phytophthora nicotianae, Phytophthora arecae (Guest, 2007). Namun hanya tiga spesies yang mengakibatkan kehilangan hasil paling besar pada kakao yaitu P. plmivora, P. megakarya, P. citrophthora (McMahon dan Purwantara, 2004). Hasil laporan yang diperoleh paling banyak menyebabkan kerugian di Indonesia pada hasil kakao yaitu disebabkan oleh $P$. palmivora dikarenakan dapat menyerang semua fase pertumbuhan tanaman kakao dan yang paling buah menjadi busuk dan layu Cherelle (Acebo et al., 2012).

Gejala awal infeksi pada busuk buah kakao yaitu terdapatnya bercak hitam pada buah seiring dengan pertumbuhan bercak terus berkembang menutupi permukaan buah dan menyerang bagian jaringan internal buah. Patogen P. palmvora menyebabkan biji kakao berubah warna, buah yang terinfeksi menjadi kehitam dan menciut dalam waktu 2 minggu (Guest, 2007; Jackson dan Wright, 2001).

Pengendalian penyakit yang sering dilakukan yaitu dengan pengendalian yang dilakukan dengan mengunkan bahan kimia, sanitasi kebun serta melakukan penanaman klon yang tahan terhadap penyakit (Bagian Proyek Penelitian Kopi dan Kakao, 2001). Petani kakao pada umumnya masih menggunakan fungisida sintetis untuk mengendalikan cendawan patogenik. Kesadaran masyarakat saat ini mulai meningkat dengan adanya peringatanperingatan dan sosialisasi terhadap bahaya lingkungn dan kesehatan sehingga penggunaan bahan kimia sintetis mulai dibatasi. Pengunaan bahan kimia (fungisida) yang terus menerus dilakukan justru menyebabkan penyakit tahan dan belum tentu dengan penggunaan tersebut efektif. Penggunaan fungisida yang berlebihan dapat memberikan dampak terhadap keamanan produk, pangan dan kesehatan (Bruin dan Edgington 1980; Charles, 1997).

Upaya yang dapat dikembangkan untuk mngurangi pemakaian fungisida buatan adalah dengan pemanfaatan rizobakteri pada rizosfer tanaman (pengendalian secara biologi). Rizobakteri merupakan bakteri endosit yang hidup di daerah perakaran tanaman. Rizobakteri berkemampuan sebagai agen antagonis patogen tanaman dan dapat berperan sebagai pemicu pertumbuhan tanaman. Kemampuan rizobakteri telah banyak dilaporkan efektif meningkatkan ketahanan tanaman terhadap infeksi jamur, bakteri dan virus (Niranjan et al., 2005). Mekanisme ketahanan ini diperoleh melalui senyawa pertahanan yang aktif ketika adanya serangan patogen (Viswanathan et al., 2001).

Kemampuan induksi resisten sistemik (ISR) terhadap berbagai jenis penyakit juga didapatkan melalui mekanisme rizobakteri sebagai Plant Growth Promoting Rhyzobacteria (PGPR) (Chen et al., 2000; Liu et al.,1995). Jenis mikroba yang dapat digunakan untuk mengendalikan cendawan atau patogen yaitu Trichoderma virens, Bacillus subtilis, 
Agrobacterium radiobacter, Bacillus cereus, Baillus amyloliquefaciens, Pseudomonas fluorescens, Saccharomyces sp, Gliocadium sp, Burkholderia cepacia (Suprapta, 2012).

Bakteri yang memiliki kemampuan untuk menghalangi perkembangan pertumbuhan Ralstonia solanacearum dan Meloidogyne incognita yaitu bakteri Bacillus spp., P. fluorescens dan Streptomyces spp (Djatmiko et al., 2007). Sehubungan dengan beberapa hasil penelitian tersebut, terkait dengan penggunaan isolat bakteri yang mempu mengendalikan patogen P. palmivora secara In Vitro.

\title{
METODE PENELITIAN
}

Maret hingga Juni 2018 telah dilaksankannya penelitian mengenai identifikasi kemampuan isolat bakteri dari rizosfer kakao terhadap daya hambat patogen Phytophthora palmivora secara in vitro. Pelaksanaan dilakukan di Laboraturium Ilmu dan Teknologi Benih Program Studi Agroteknologi, Fakultas Pertanian, Universitas Syiah Kuala, Darussalam Banda Aceh.

\begin{abstract}
Alat dan Bahan
Alat dan bahan yang digunakan dalm penelitian ini yaitu incubator, ruang inkubasi, vortex, kompor gas, autoclave, ayakan, cork borrer, jarum ose, Laminar air flow, timbangan analitik, pipet ukur, lampu bunsen, oven listrik, cangkul, pisau, saringan, alat tulis, kamera, erlenmeyer, tabung reaksi, cawan petri, dan spatula, mikroskop. Bahan-bahan yang telah digunakan yaitu sampel buah kakao yang terserang $P$. palmivora, tanah rizosfer tanaman kakao dari Kabupaten Nagan Raya yang akan dilakukan isolasi untuk mendapatkan rizobakteri, media Sucrose Peptone Agar (SPA), Potato Dextrose Agar (PDA), tissu, karet gelang, chloram-phenicol, kapas, spiritus, plastik tahan panas, natrium hipoklorit, aquadest, kertas label, aluminium foil, plastik wrap, dan alkohol.
\end{abstract}

\section{Rancangan Penelitian}

Rancangan Acak Lengkap (RAL) non Faktorial yaitu rancangan yang digunakan pada penelitian ini. Isolat bakteri yang diperoleh sebanyak 19 isolat yang diperoleh dari uji awal yang diulang sebanyak 3 kali ulangan sehingga didapat 57 satuan peroabaan. Faktor yang diteliti dalam penelitian ini yaitu persentase daya hambat dan laju hambat isolat bakteri. Metode yang digunakan dalam penelitian ini yaitu metode eksploratif dan metode eksperimen. Metode yang digunakan untuk mengisolasi patogen dan mengisolasi bakteri kandidat agens biokontrol merupakan metode eksploratif, sedangkan uji antagonis 19 isolat bakteri hasil isolasi dengan patogen $P$. palmivora media PDA merupakan metode eksperimen. Jika pada taraf 5\% berpengaruh nyata maka akan dilakukan uji lanjut BNJ (Beda Nyata Jujur) terhadap nilai rata-rata perlakuannya untuk mengetahui perbedaan antar tarafnya (Steel dan Torrie, 1991).

\section{Prosedur Penelitian}

\section{Sterilisasi Alat}

Sterilisasi alat menggunakan oven listrik dengan suhu $121{ }^{\circ} \mathrm{C}$ dimana semua alat yang akan digunakan sebelum measuki ruan laminar air flow disterilkan semua. Tahap pertama sebelum alat masuk kedalam oven listrik semua alat dicuci bersih, selanjutnya dikeringkan dengan oven listrik selama 15-20 menit dengan suhu sektira $40{ }^{\circ} \mathrm{C}$. Jika alat telah kering 
maka dilakukan pembungkusan dengan kertas koran. Pensterilan dilakukan selama 4 jam (Lay dan Hastowo, 1992).

\section{Pembuatan Meedia Potato Dextrose Agarr}

$200 \mathrm{~g}$ kentang dicucii bersih dengan air mengalir yang telah dikupas kulit kentangnya. Kentang selanjutnnya dipotong dengan ukuran $1 \mathrm{~cm} \times 1 \mathrm{~cm}$ dan dimasukkan kedalam beaker glass, kemudian ditambahkan aquades sebanyak $500 \mathrm{ml}$ dan direbus dengan menggunakan kompor hingga mendidih sampai kentang berstekstur empuk dan mengeluarkan sarinya. Setelah kentang mendidih kemudian disaring dengan menggunakan saringan. Hasil ekstrak kentang ditambahkan dengan 15 g agar-agar, 15 g dextrose dan aquades hingga $1000 \mathrm{ml}$, kemudian dididihkan dan diaduk secara merata sampai larutan tersebut larut. Larutan PDA yang dihasilkan dimasukkan kedalam erlenmeyer $1000 \mathrm{ml}$ yang ditutupi dengan alumunium foil dan plastik anti panas serta diikat dengan karet gelang. PDA disterilkan selama 15 menit dengan suhu $121-124{ }^{\circ} \mathrm{C}$. Media PDA yang telah steril didinginkan sebelum dilakukan penuangan ke cawan petri.

\section{Deteksi, Isolasi dan Identifikasi Patogen P. palmivora}

Patogen P. palmivora dideteksi dan diidentifikasi di Laboratorium Ilmu dan Teknologi Benih. Diambil bagian buah kakao yang terinfeksi penyakit P. palmivora di daerah Tripa. Kemudian diisolasi dengan cara dipotong kulit bagian permukaan buah batas antara yang sehat dan yang sakit sebesar $0,5 \mathrm{~cm}$ x $0,5 \mathrm{~cm}$ dengan menggunakan pisau steril. Desinfektan yang digunakan untuk mengurangi kontainasi yaitu hipoklorit yang $2 \%$ dengan bahan isolasi atau potongan perbukaan buah kakao direndam selama 5 menit didalam hipoklorit. Pembilasan setelah perendaman hipoklorit dilakuakn sebnayak 3 kali dengan aquades steril. Isolat bakteri yang mrni diperoleh dari subkultur dan diinkubasi kurang lebih selama 7 hari dengan penyinaran NUV 12 jam terang dan 12 jam gelap dan suhu ruang $27-29{ }^{\circ} \mathrm{C}$ kemudian dilakukan peremajaan. Selanjutnya dilakukan identifikasi 19 isolat bakteri yang diperoleh dengan cara pengamatan mikroskopik dan makroskopik karakter kultur.

\section{Bakteri Kandidat Agen Biokontrol diisolasi dari Tanah Daerah Rizosfer Tanaman Kakao}

Sampel tanah diambil pada pertanaman kakao petani di daerah Tripa Makmur Kabupaten Nagan Raya. Isolasi isolat bakteri dilakukan pada daerag rizosfer tanaman kakao yang sehat diantara tanaman kakao yang terkena serangan penyakit. Sebanyak $1 \mathrm{~kg}$ sampel tanah pada setiap lokasi dihomogenkan dan dikering anginkan selama satu hari. Sampel tanah disaring dengan menggunakan saringn 9 mesh dan dilakukan isolasi di Laboratorium Ilmu dan Teknologi Benih.

\section{Pembuatan Media SPA}

Media yang digunakan sebagai tempat tumbuh bakteri yaitu media Sucrose Pepton Agar. Media tersebut terkenal sebagai media tempat terbaik untuk menumbuhkan bakteri. Bahan-bahan untuk membuat Sucrose Pepton Agar ditimbang dengan menggunakan timbangan analitik yaitu penimbangan terhadap Sukrosa $20 \mathrm{~g}, \mathrm{~K}_{2} \mathrm{HPO}_{4}$ (tanpa air) 0,5 g, Pepton $5 \mathrm{~g}, \mathrm{MgSO}_{4} 7 \mathrm{H}_{2} \mathrm{O}$ 0,25 g, Bacto Agar $12 \mathrm{~g}$, setelah penimbangan dimasukkan bahan kedalam 1 liter aquades steril kemudian dihomogenkan. Pensterilan media dilakukan pada suhu $120^{\circ} \mathrm{C}$ selama 4 jam dengan menggunakan autoclave. Kemudian didinginkan untuk dilakukan penuangan media kedalam cawan petri dalam laminar air flow. 


\section{Isolasi bakteri sebagai Penghambat Patogen}

Isolat bakteri diisolasi dengan melakukan pengenceran berseri. Disiapkan 9 tabung reaksi dan 1 tabung reaksi sebagai biang yang berisi $10 \mathrm{ml}$ aquades steril dan $1 \mathrm{~g}$ sampel tanah. Delapan tabung reaksi berisi $9 \mathrm{ml}$ aquades steril tabung ${ }^{-1}$. Tabung reaksi sebagai biang di homogenkan dengan menggunakan vortex, kemudian diambil $1 \mathrm{ml}$ suspensi tanah dari tabung reaksi tersebut dan dimasukkan ke tabung reaksi pertamaa secara aseptis yang disebut pengenceran pertama $\left(10^{-1}\right)$ kemudian diulang hingga pengenceran ke delapan $\left(10^{-8}\right)$. Suspensi pengenceran dari $10^{-3}$ hingga $10^{-8}$ ditanam dengan mengambil $0,1 \mathrm{ml}$ suspensi dan dituang kedalam media SPA. Koloni dari masing-masing rizobakteri kemudia disubkulturkan untuk mendapatkan isolat murni rizobakteri.

\section{Uji Awal Penghambatan Pertumbhan Patogen P. palmivora dengan Melihat Daya Hambat Isolat Bakteri}

Uji awal pada isolat bakteri yang diperoleh dari isolasi di rizosfer tanaman kakao untuk melihat seberapa banyak isolat bakteri yang miliki potensi dalam menghambat patogen, seleksi dilakukan pada media PDA dengan meletakkan patogen yang berukuran $0,5 \mathrm{~cm}$ ditengah cawan petri dan meletakkan 4 isolat bakteri yang jaraknya 2,25 $\mathrm{cm}$ dengan patogen (Gambar 1).

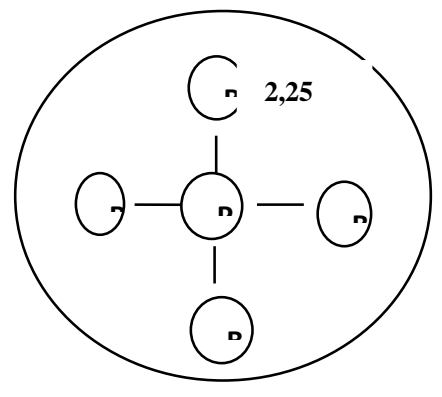

Ket : $\begin{aligned} \mathrm{B}=\text { Bakteri } \\ \mathrm{P}=\text { Patogen }\end{aligned}$

Gambar 1. Gambaran letak bakteri dan patogen terhadap uji awal daya hambat

Ukuran yang menjadi dasar penilaian untuk memilih isolat bakteri yang akan digunakn sebagai agen antogonis yaitu bakteri yang muncul paling awal dengan ukuran koloni bakterinya yang tumbuh memenuhi petri warna serta bentuk yang jelas, bakteri yang membentuk zona hambatan terhadap pertumbuhan patogen. Isolat bakteri yang diperoleh dengan kriteria tersebut akan dilakukan pengujian selanjutnya yaitu duel antara bakteri dan patogen atau disebut uji kultur ganda.

\section{Uji Kultur Ganda (Duel) Isolat Bakteri terhadap Patogen Busuk Buah Kakao}

Kandidat isolat rizobakteri yang telah terseleksi pada uji awal kemudian diuji antagonisnya untuk melawan patogen P. palmivora dengan cara duel. Diletakkan potongan cendawan (ukuran $0.5 \mathrm{~cm}$ ) pada petri yang telah tumbuh rizobakteri antagonis yang tumbuh memenuhi petri yaitu rizobakteri umur 4 hari, pengujian dilakukan pada media Potato Dextros Agar dengan ukuran diameter petri $9 \mathrm{~cm}$. Letak jarak rizobakteri dengan patogen berjarak 3 $\mathrm{cm}$ (Gambar 2). Pengujin diinkubasikan pada temperatur ruangan (27-29 $\left.{ }^{\circ} \mathrm{C}\right)$, kemudian dilakukan pengamatan setiap hari hingga 7 hari. 


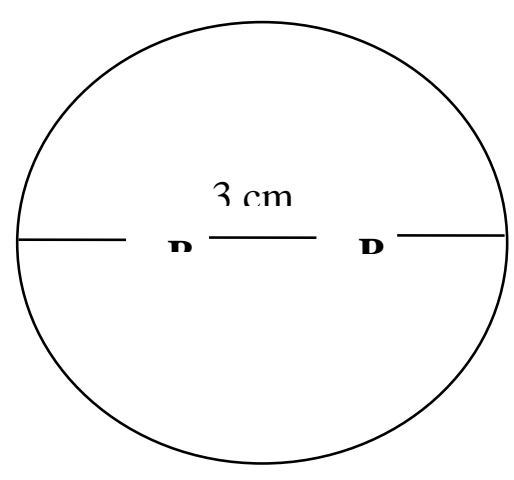

Ket : $B=$ Bakteri

$\mathrm{P}=$ Patogen

Gambar 2. Gambaran uji kultur ganda anatara isolat bakteri dan patogen

\section{Parameter Pengamatan}

Persentase Daya Hambat Pertumbuhan Koloni Patogen

Persentase Daya Hambat terhadap patogen diukur dengan menggunakan rumus Soytong (1988) :

Keterangan :

$$
\mathbf{P P}=\frac{R 1-R 2}{R 1} \mathbf{X 1 0 0} \%
$$

PP = Persentase Daya Hambat Pertumbuhan Koloni Patogen

R1 = Jari-Jari Koloni Patogen yang Tumbuhnya Menjauhi Agen Antagonis (cm)

R2 = Jari-Jari Koloni Patogen yang Tumbuhnya Ke Arah Agen Antagonis (cm)

Klasifikasi Daya hambat isolat bakteri dilihat berdasarkan nilai persentase dari pertumbuhan patogennya yaitu dengen pengklasifikasian aktivitas sebagai berikut: aktivitas sangat tiinggi $(++++=>75 \mathrm{DHM})$, aktivitas tingi $(+++=61-75 \mathrm{DHM})$, aktivtas sedang $(++=$ 51-60DHM), aktivitas rendah $(+=\leq 50 \mathrm{DHM})$ dan tidak ada aktivitass $(-)$.

\section{Laju Hambatan Perkembangan Koloni Patogen}

Satuan dari laju hambatan Perkembangan koloni pathogen yaitu $\mathrm{mm} / \mathrm{hari}$, yang diamati selama 7x24 jam. Rumus untuk melakukan pengukuran laju hambatan perkembangan koloni patogen yaitu:

$$
\mathbf{L P P K}=\int_{7}^{0}\left[\frac{X i-(X i-1)}{T i}\right]
$$

Keterangan: $\quad$ LPPK = Laju Hambatan Perkembangan Koloni Patogen

$\mathrm{X} i=$ Panjang diameter koloni patogen pada pengamatan ke-i

$\mathrm{T} i=$ Waktu Pengamatan dinyatakan dalam hari 


\section{HASIL DAN PEMBAHASAN}

\section{Hasil Penelitian}

\section{Isolasi Bakteri dan Patogen Pada Daerah Rizosfer Tanaman Kakao}

Hasil eksplorasi dan isolasi rizobakteri pada tanah rizosfer perkebunan kakao daerah Tripa Makmur Kabupaten Nagan Raya diperoleh 65 isolat murni rizobakteri (Tabel 1) dengan cara melakukan penanaman suspensi tanah di media SPA yang sebelumnya dilakukan pengenceran berseri terlebih dahulu, pemurnian selanjutnya dilakukan untuk mendapatkan isolat murni bakteri. Sedangkan busuk buah kakao diisolasi di Laboratorium Ilmu dan Teknologi Benih. Hasil isolasi busuk buah kakao kemudian dimurnikan beberapa kali untuk mendapatkan cendawan patogen P. palmivora. Karakteristi morfologi yang dilihat untuk memurnikan P. palmivora yaitu tepi koloni dan bentuk miselium. Tepi koloni yang diamati terlihat tidak rata atau tidak beraturan kemudian bentuk miseliumnya yang tampak datar, patogen bewarna putih seperti kapas dari hasil pengamatan isolat P. palmivora secara makroskopis (Gambar 3a). Dilihat dari pengamatan mikroskopis bentuk dari sporangia terlihat jelas berbentuk ovoid (Gambar 3b) dan terdapat papilla pada ujungnya (Gambar 3b.1). Zoospore berada didalam sporangium (Gambar 3b.2) dan Bentuk dari klamidospore terlihat bulat dengan dinding selnya yang agak tebal (Gambar 3.b.3).

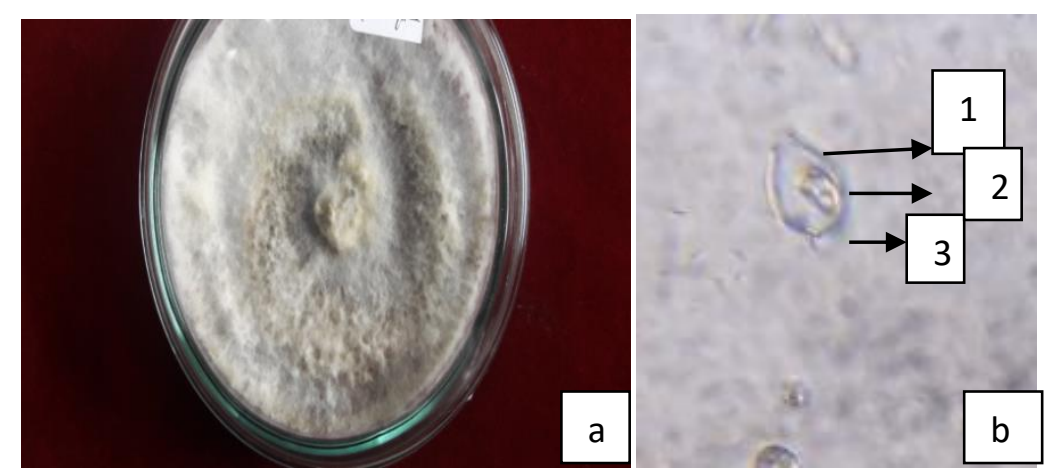

Gambar 3. (a). Koloni jamur P. palmivora, (b). 1. Papilla, 2. Zoospore, 3. Klamidospore yang tampak pada mikroskop pembesaran 400x 
Tabel 1. Isolat Bakteri Hasil Isolasi dari Rizosfer Tanaman Kakao

\begin{tabular}{llllll}
\hline & \multicolumn{5}{c}{ Rizobakteri Daerah Tripa Makmur } \\
TRIM3/1 & TRIM4/1 & TRIM4/12 & TRIM6/3 & TRIM6/14 & TRIM8/1 \\
TRIM3/2 & TRIM4/2 & TRIM5/1 & TRIM6/4 & TRIM6/15 & TRIM8/2 \\
TRIM3/4 & TRIM4/4 & TRIM5/3 & TRIM6/6 & TRIM7/2 & TRIM8/4 \\
TRIM3/5 & TRIM4/5 & TRIM5/4 & TRIM6/7 & TRIM7/3 & TRIM8/5 \\
TRIM3/6 & TRIM4/6 & TRIM5/5 & TRIM6/8 & TRIM7/4 & TRIM8/6 \\
TRIM3/7 & TRIM4/7 & TRIM5/6 & TRIM6/9 & TRIM7/5 & TRIM8/7 \\
TRIM3/8 & TRIM4/8 & TRIM5/7 & TRIM6/10 & TRIM7/6 & TRIM8/8 \\
TRIM3/9 & TRIM4/9 & TRIM5/8 & TRIM6/11 & TRIM7/7 & TRIM8/9 \\
TRIM3/10 & TRIM4/10 & TRIM6/1 & TRIM6/12 & TRIM7/8 & TRIM8/10 \\
TRIM3/11 & TRIM4/11 & TRIM6/2 & TRIM6/13 & TRIM7/9 & \\
\hline
\end{tabular}

Keterangan : TRI $=$ Tripa

\section{Uji Awal Daya Hambat dan Aktivitas Daya Hambat Isolat Bakteri terhadap Pertumbuhan Patogen P. palmivora}

65 isolat bakteri yang telah dimurnikan diperoleh dari pemurnian beberapa kali (Tabel 1) untuk memperoleh isolat bakteri yang mampu menghambat pertumbuhan dan perkembangan patogen dilakukan pengujian awal terlebih dahulu sehingga dari hasil uji awal yang dilakukan didapat 19 isolat yang dapat kita jadikan agen antagonis. Terpilihnya 19 isolat tersebut sesuai dengan karakteristik yang diamati yatiu melihat pertumbuhan koloni bakteri yang muncul paling awal dengan bentuk dan warna yang jelas. Pertumbuhan yang diamati yaitu tumbuh paling awal, bentuk yaitu yang membentuk zona hambatan serta pigmen warna yang dikeluarkan bateri paling jelas. 19 isolat tersebut terdiri dari TRIM3/3, TRIM3/4, TRIM 3/11, TRIM4/6, TRIM4/7, TRIM4/10， TRIM6/6， TRIM6/13， TRIM6/14, TRIM6/15, TRIM7/1， TRIM7/2， TRIM7/4， TRIM8/2， TRIM8/4， TRIM8/6， TRIM8/8， TRIM8/9， TRIM8/10.

Tabel 2 dan Tabel 3 menunjukkan bahwa persentase daya hambat dan laju hambat perkembangan P. palmivora terdapat pada isolat bakteri TRIM8/9 yang terbaik dengan nilai persentase $76,67 \%$ dan laju hambat dengan nilai $3,16 \mathrm{~mm} /$ hari. Sedangkat Aktivitas menunjukkan aktivitas sangat tinggi $(++++=>75 \%$ DHM) pada isolat yang sama. 
Tabel 2. Rata-rata Persentase (\%) Daya Hambat dan Aktivitas Daya Hambat Isolat Bakteri terhadap Perkembangan P. palmivora

\begin{tabular}{|c|c|c|}
\hline \multirow{2}{*}{$\begin{array}{l}\text { Rizobakteri } \\
\text { Agens } \\
\text { Biokontrol }\end{array}$} & \multirow[t]{2}{*}{$\begin{array}{c}\text { Daya Hambat terhadap } \\
\text { Patogen }(\%)\end{array}$} & \multirow{2}{*}{$\begin{array}{c}\text { Aktivitas Daya Hambat terhadap Patogen } \\
\text { P. palmivora }\end{array}$} \\
\hline & & \\
\hline TRIM3/3 & $28,89 \mathrm{de}$ & + \\
\hline TRIM3/4 & $2,22 \mathrm{a}$ & + \\
\hline TRIM3/11 & $0,00 \mathrm{a}$ & + \\
\hline TRIM4/6 & $12,22 \mathrm{~b}$ & + \\
\hline TRIM4/7 & $0,00 \mathrm{a}$ & + \\
\hline TRIM4/10 & $12,22 b$ & + \\
\hline TRIM6/6 & $22,22 \mathrm{c}$ & + \\
\hline TRIM6/13 & $59,44 \mathrm{hi}$ & ++ \\
\hline TRIM6/14 & $40,00 \mathrm{f}$ & + \\
\hline TRIM6/15 & $48,89 \mathrm{~g}$ & + \\
\hline TRIM7/1 & $65,55 \mathrm{i}$ & +++ \\
\hline TRIM7/2 & $24,44 \mathrm{~cd}$ & + \\
\hline TRIM7/4 & $55,55 \mathrm{~h}$ & ++ \\
\hline TRIM8/2 & $30,00 \mathrm{e}$ & + \\
\hline TRIM8/4 & $56,67 \mathrm{~h}$ & ++ \\
\hline TRIM8/6 & $62,22 \mathrm{i}$ & +++ \\
\hline TRIM8/8 & $48,89 \mathrm{~g}$ & + \\
\hline TRIM8/9 & $76,67 \mathrm{j}$ & ++++ \\
\hline TRIM8/10 & $56,11 \mathrm{~h}$ & ++ \\
\hline
\end{tabular}

BNJ 5\% 5,29

Keterangan : - Angka yang diikuti oleh huruf yang sama pada kolom yang sama berbeda tidak nyata pada Uji Beda Nyata jujur (BNJ) $\alpha=0,05$.

- Aktivitas sangat tinggi $(++++=>75 \%$ DHM), aktivitas tinggi $(+++=61-75 \%$ DHM), aktivitas sedang $(++=51-60 \% \mathrm{DHM})$, aktivitas rendah $(+=<50 \% \mathrm{DHM})$ dan tidak ada aktivitas $(-)$ 
Tabel 3. Laju Hambat Perkembangan Isolat Bakteri terhadap Perkembangan P. palmivora

\begin{tabular}{cc}
\hline $\begin{array}{c}\text { Rizobakteri } \\
\text { Agen Biokontrol }\end{array}$ & $\begin{array}{c}\text { Laju Penghambatan Rizobakteri } \\
(\mathrm{mm} / \mathrm{hari})\end{array}$ \\
\hline TRIM3/3 & $5,98 \mathrm{ab}$ \\
TRIM3/4 & $6,55 \mathrm{ab}$ \\
TRIM3/11 & $6,46 \mathrm{ab}$ \\
TRIM4/6 & $6,23 \mathrm{ab}$ \\
TRIM4/7 & $6,90 \mathrm{~b}$ \\
TRIM4/10 & $6,38 \mathrm{ab}$ \\
TRIM6/6 & $6,06 \mathrm{ab}$ \\
TRIM6/13 & $5,91 \mathrm{ab}$ \\
TRIM6/14 & $6,02 \mathrm{ab}$ \\
TRIM6/15 & $5,55 \mathrm{ab}$ \\
TRIM7/1 & $5,66 \mathrm{ab}$ \\
TRIM7/2 & $6,63 \mathrm{~b}$ \\
TRIM7/4 & $5,76 \mathrm{ab}$ \\
TRIM8/2 & $6,56 \mathrm{~b}$ \\
TRIM8/4 & $5,92 \mathrm{ab}$ \\
TRIM8/6 & $3,97 \mathrm{ab}$ \\
TRIM8/8 & $4,94 \mathrm{ab}$ \\
TRIM8/9 & $3,16 \mathrm{a}$ \\
TRIM8/10 & $3,95 \mathrm{ab}$ \\
BNJ 5\% & 3,39 \\
\hline Anga yang
\end{tabular}

Keterangan : Angka yang diikuti oleh huruf yang sama pada kolom yang sama berbeda tidak nyata pada Uji Beda Nyata jujur (BNJ) $\alpha=0,05$

\section{Pembahasan}

Dari hasil pengamatan morfologi P. palmivora secara mikroskopis sesuai dengan penelitian yang telah dilakukan oleh Murtalo et. al (2007) yang menunjukkan sporangia dari patogen tersebut berbentuk ovoid serta papillanya yang terlihat jelas. Papilla memiliki fingsi sebagai tempat keluar zoospore. Klamidospore yang memiliki fungsi sebagai spora resisten serta memiliki dinding yang tebal. Sedangkan pengamatan makroskopis terlihat bentuk miselium yang tidak datar dan koloninya terlihat tidak datar.

Hasil penelitian setelah diperolehnya isolat murni dari patogen dan isolat bakteri murni sebanyak 19 isolat dideteksi sebagai agen biokontrol di uji kemampuannya dengan melakukan duel antara patogen dan isolat bakteri. Terdapat satu isolat yang sangat berpotensi sebagai kandidat (TRIM8/9) dan dua isolat lain yang berpotensi sedang (TRIM7/1 dan TRIM8/6). TRIM8/9 memiliki nilai persentase paling tinggi dan aktivitas paling tinggi serta laju hambat perkembangan koloni patogen terbaik, diduga TRIM8/9 mampu menghambat perkembangan pertumbuhan koloni, hifa dan jumlah spora mengecil. TRIM8/9 diyakini menghambat sintesis protein sehingga mengakibatkan terganggunya perkembangan pertumbuhan patogen, penelitian dari Wang et.al (2005) juga mengatakan bahwa rizobakteri mampu mensintesiis protein cendawan. Adanya kompetisi antara isolat bakteri dan patogen di in vitro selama pengujian mengakibatkan keduanya melakukan perebutan nutrisi serta tempat sehingga berpengaruh terhadap pertumbuhan dari keduanya, namun kemampuan bakteri yang 
dapat mengeluarkan senyawa-senyawa berupa enzim, toksin dan antibiotik dapat menekan pertumbuhan dari patogen selama pengujian in vitro.

Schaechter (2004) melakukan penelitian uji kultur ganda bakteri P. flurescence dan B. subtilis terhadap P. palmivora. Nilai persentase yang didapat dari hasil uji kultur ganda antara P. flurescence dan P. palmivora 69,5\% sedangkan B. subtilis dan P. palmivora 72,8\%. Kemampuan bakteri dalam menghasilkan peptida yang memiliki fungsi sebagai antibiotik dan antifungi sehingga mendapatkan nilai persentase tinggi. Meloidogyne incognita ketika diaplikasikan Pseudomonas sp dan Bacillus sp terbukti nyata mengurangi serangan penyakit tersebut pada tanaman Vigna mungo (Akhtar et al., 2012). Penelitian Muharni dan Widjajanti (2012) strain Bacillus sp dan Bacillus apiarus yang diisolasi dari perakaran tanaman karet secara efektif menghambat pertumbuhan koloni patogen jamur akar putih.

Kelompok bakteri B. amyloliquefaciens dan B. siamensis yang diperoleh dari isolasi rizosfer tanaman karet memiliki potensi untuk mengendalikan $R$. lignosus penyebab penyakit akar putih. Kedua isolat tersebut mampu menghambat $50 \%$ dengan nilai hambat $70,0 \%$ untuk B. amyloliquefaciens dan B. siamensis dengan nilai hambat 62,5\% (Hardiyanti, 2017).

Senyawa volatile berupa amonia, hidrogen sianida $(\mathrm{HCN})$ dan alkil piron dapat merauni mikroba, bakteri yang mampu menghasilkan senyawa tersebut yaitu Pseudomonas. Pseudomonas juga mampu memproduksi substansi ekstraselular seperti antibiotik, enzim kitinase dan protease sehingga menekan perkembangannya pesaingnya (Compant et al., 2005). Menurut Gupta et al. (2006) kemampuan enzim kitinase dapat menyebabkan terjadinya abnormalitas hifa jamur target seperti perforasi, lisis dan terfragmentasi. Rizobakteri yang juga menghasilkan senyawa siderofor dan hidrogen sianida $(\mathrm{HCN})$ juga berperan penting dalam aktivitas biokontrol pertumbuhan koloni patogen.

\section{SIMPULAN DAN SARAN}

Isolat bakteri dari hasil isolasi pada rizosfer tanaman kakao di daerah Tripa Makmur didapatkan 65 isolat bakteri. Uji awal isolat bakteri terhadap daya hambat $P$. palmivora menunjukkan bahwa 19 isolat bakteri berpotensi sebagai kandidat agen biokontrol. Isolat bakteri TRI 8/9 memiliki persentase daya hambat dan aktivitas daya hambat terbaik yaitu 76,67\% dengan aktivitas sangat tinggi. Laju penghambatan isolat bakteri TRI 8/9 mampu menghambat perkembangan terbentuknya spora, koloni dan hifa rendah dengan nilai laju hambat isolat bakteri yaitu $3,16 \mathrm{~mm} / \mathrm{hari}$.

Disarankan untuk melakukan penelitian lebih lanjut terhadap kemampuan isolat bakteri yang telah didapatkan dengan melakukan penelitian di lapangan terhadap kemampuannya sebagai agen biokontrol.

\section{DAFTAR PUSTAKA}

Acebo, Y., A. Hernández., M. Heydrich dan M. El Jaziri. 2012. Management of black pod rot in cacao (Theobroma cacao L.): a review | Fruits | Cambridge Core [WWWDocument].URLhttps://www.cambridge.org/core/journals/fruits/article/ managemet-of-black-pod-rot-in-cacao-theobroma-cacao-lareview/05EC433 81B262E85818E3 C8EB99F7CF5 [3 Maret 2018]

Akhtar, A., A. Hisamuddin dan R. Sharf. 2012. Antagonistic effects of Pseudomonas flourescence and Bacillus subtilis on Meloidogyne incognita infecting Vigna 
mungo L. Internasional J. Of plants, animal, and environmental sciences. 2: 5563.

Bagian Proyek Penelitian Kopi dan Kakao. 2001. Laporan Kegiatan Penelitian Tahun Anggaran 2001. Pusat Penelitian Kopi dan Kakao, Jember.

Bruin, G. C dan L. V. Edgington. 1980. Induced resistance to ridomil of some oomycetes. Phytopathology. 70:459-560.

Charles, L. B., D. B. Benny., M. W. Bruton., Marisa dan R. Melinda. 1997. Phytophthora capsici zoospore infection of pepper fruit in variuos physical environments. Departement of Agronomy and Horticulture. New Mexico State University, Nm 88003.

Chen, C., R. R. Belanger., N. Benhamou dan T. C. Paulitz. 2000. Defense enzymes induced in cucumber roots by treatmet with plant growth-promoting rhizobacteria (PGPR) and Phytium aphanidermatum. Physiol. Mol. Plant. Pathol. 56:13-23.

Compant, S., B. Duffy., J. Nowak., C. Cle'Ment dan E. D. A. Barka. 2005. Use of plant growth-promoting bacteria for biocontrol of plant diseases. Principles, mechanisms of action, and future prospects. Applied and Environmental Microbiology. 72(9):4949-4959.

Darmono, T. W., I. Jamil dan D. A. Santoso. 2006. Pengembangan penanda molekuler untuk deteksi Phytophthora palmivora pada tanaman kakao. Menara Perkebunan. 74:86-95.

Direktorat Jenderal Perkebunan. 2016. Statistik Perkebunan Indonesia 2015-2017 Kakao. Sekretariat Direktorat Jendral, Jakarta.

Djatmiko, H. A., T. Arwiyanto., B. Hadisutrisno dan B. H. Sunarminto. 2007. Potensi tiga genus bakteri dari tiga rizosfer tanaman sebagai agensia pengendali hayati penyakit lincat. J. Ilmu-ilmu Pertanian Indonesia, 9:40-47.

Guest, D., 2007. Black pod: diverse pathogens with a global impact on cocoa yield. Phytopathology. 97(12):1650-1653.

Gupta, C. P., B. Kumar., R. C. Dubey dan D. K. Maheshwari. 2006. Chitinase-mediated destructive antagonistic potential of Pseudomonas aeruginosa GRC1 against Sclerotinia sclerotiorum causing stem rot of peanut. Biocontrol. 51(6):821-835.

Hardiyanti, T. 2017. Mikrobrizosfer dan endofit jaringan akar tanaman karet sebagai agens hayati penyakit akar putih Rigidoporus lignosus '(klotzsch) imazeki. Tesis. Institut Pertanian Bogor, Bogor.

Jackson, G. V. H dan J. G., Wright. 2001. Black pod and cancer of cacao. Pest edvisory leaflet no. 7. Plant Protection Service, Secretariot of the Pacific Community.

Lay, B. W dan S. Hastowo. 1992. Mikrobiologi. IPB. Bogor. 
Liu L., J. W. Kloepper dan S. Tuzun. 1995. Induction of systemic resistance in cucumber by plant-growth promoting rhizobacteria: duration of protection and effect of host resistance on protection and root colonization. Phytopathology. 85:1064-1068.

McMahon, P dan A. Purwantara. 2004. Phytophthora on cocoa. Divers. Manag. Phytophthora Southeast Asia. 104-114.

Motulo, H. F. J., M. S. Sinaga., M. A. Hartana., G. Suastika dan H. Aswidinnoor. 2007. Karakter morfologi dan molekuler isolat Phytophthora palmivora asal kelapa dan kakao. J. Litri. 13:111-118.

Muharni dan Widjajanti. 2012. Skrining bakteri kitinolitik antagonis terhadap pertumbuhan jamur akar putih (Rigidoporus lignosus) dari rizosfir tanaman karet. J. Penelitian Sains. 14(1):63-76.

Niranjan, S., N. P. Shetty dan H. S. Shetty. 2005. Seed biopriming with Pseudomonas fluorescens isolate enhances growth of pearl millet plant and induces resistance against downy mildew. International J. of Pest Management. 50(1):41-48.

Rosmana, A., C. Waniada., M. Junaid dan A. Gassa. 2010. Peranan semut Iridomirmex cordatus (Hyminoptera: Formicidae) dalam menularkan patogen busuk buah Phytophthora palmivora. Pelita Perkebunan. 26:169-176.

Schippers, B., A. W. Bakker dan P. A. H. M. Bakker. 1987. Interactions of deleterious and beneficial rhizosphere microorganisms and the effect of cropping practices. Annu. Rev. Phytopathol. 25:339-358.

Soytong, K. 1988. Identication of spescies Chaitomiumin the Philippines and screening Colletotrichum dematiumon cowpea seed. Seed Sci. Technol. 27:591-598.

Statistik Perkebunan Indonesia. 2017. Provinsi Aceh dalam Angka 2017. Banda Aceh, Aceh.

Steel, R. G dan J. H. Torrie. 1991. Prinsip dan Prosedur Statistika. PT Gramedia Pustaka Utama, Jakarta.

Sunanto, H. 1992. Cokelat, Budidaya, Pengolahan Hasil dan Aspek Ekonominya. Kanisius, Yogyakarta.

Suprapta, D. N. 2012. Potential of microbial antagonists as biocontrol agents against plant fungal pathogens. J. ISSAAS. 18:1-8.

Viswanathan, R dan R. Samiyappan. 2001. Antifungal activity of chitinase produced by some fluorescent pseudomonads against Colletotrichum falcatum Went causing red rot disease in sugarcane. Microbiological Research. 155:309-314.

Wang, S., J. Wu., P. Rao dan X. Ye. 2005. A chitinase with antifungal activity from the mung bean. Protein Expr. Purif. 40:232-236. 